\title{
CHANGES IN EEG PATTERNS IN THE $\alpha$-FREQUENCY BAND FOLLOWING BCI-BASED THERAPY IN CHILDREN WITH CEREBRAL PALSY
}

Larina NV, Nacharova MA, Korsunskaya LL, Vlasenko SV, Pavlenko VB $\square$

Vernadsky Crimean Federal University, Simferopol, Russia

It was demonstrated previously that neurorehabilitation with the noninvasive $\mathrm{BCl}$-controlled robotic device combined with conventional therapeutic modalities resulted in significant motor improvement in children with cerebral palsy. However, EEG records were not analyzed in the previous study. The aim of this paper was to describe the reactivity patterns of the EEG $\alpha$-rhythm during a series of $10 \mathrm{BCl}$-based neurorehabilitation sessions. The study was carried out in 32 boys and girls aged 10 to 18 years with right- or left-side hemiparesis. EEG was recorded from 21 electrodes at rest and during kinesthetic imagery of finger extension. During the first session, patterns of $\alpha$-rhythm reactivity during motor imagery differed between patients with left- and right-side hemiparesis. The differences were statistically significant at P2 during left hand movement rehearsal $\left(F_{1,30}=5.10 ; p<0.05\right)$. During the final session, the pattern of $\alpha$-rhythm reactivity was different: synchronization was taken over by desynchronization at some electrode sites, suggesting increased activity of the neocortex. The most conspicuous EEG changes were observed in children with left-side hemiparesis $\left(F_{20,300}=1.84 ; p<0.05\right)$. By the end of the rehabilitation course, the differences between patients with leftand right-side hemiparesis became much less pronounced. Rearrangements in the EEG patterns in the $\alpha$-frequency band can be regarded as signs of beneficial reorganization of neural circuits responsible for planning and executing complex hand movements.

Keywords: cerebral palsy, EEG, neurorehabilitation, brain-computer interface, motor imagery

Funding: the study was part of the state-funded project RFMEFI60519X0186 on the Development of a BCl-based hand exoskeleton with biological feedback for the rehabilitation of children with cerebral palsy. The study was supported by the Ministry of Science and Higher Education of the Russian Federation.

Author contribution: Larina NV, Korsunskaya LL, Vlasenko SV — data acquisition, manuscript preparation; Nacharova MA, Pavlenko VB — data analysis, manuscript preparation.

Compliance with ethical standards: the study was approved by the Ethics Committee of Vernadsky Crimean Federal University (Protocol № 53 dated December 06, 2018). Informed consent was obtained from the patients or their legal representatives.

$\triangle$ Correspondence should be addressed: Vladimir B. Pavlenko Pr. Vernadskogo, 4, Simferopol, 295007; vpav55@gmail.com

Received: 16.06.2020 Accepted: 02.07.2020 Published online: 16.07.2020

DOI: $10.24075 /$ brsmu.2020.043

\section{ИЗМЕНЕНИЕ ЭЭГ В ЧАСТОТНОМ ДИАПАЗОНЕ $\alpha$-РИТМА У ДЕТЕЙ С ДЕТСКИМ ЦЕРЕБРАЛЬНЫМ ПАРАЛИЧОМ ПРИ ПРИМЕНЕНИИ РОБОТИЗИРОВАННОЙ ТЕРАПИИ}

Н.В.Ларина, М.А.Начарова, Л. Л. Корсунская, С.В.Власенко, В.Б.Павленко

Крымский федеральный университет имени В. И. Вернадского, Симферополь, Россия

Курс нейрореабилитации с применением комплекса «неинвазивный интерфейс мозг-компьютер и экзоскелет кисти» в сочетании с традиционным курортным лечением приводит у детей с ДЦП к значимому улучшению паказателей движений, однако характеристики ЭЭГ не были проанализированы. Целью работы было определить особенности реактивности ЭЭГ пациентов в частотном диапазоне $\alpha$-ритма при прохождении курса из 10 сеансов роботизированной терапии. ЭЭГ регистрировали в 21 отведении в условиях покоя и кинестетического воображения движений разгибания пальцев рук у 32 детей обоего пола в возрасте 10-18 лет, имеющих диагноз «лево- и правосторонний гемипарез». Во время первого сеанса паттерны реактивности а-ритма при воображении движений у групп детей с лево- и правосторонним гемипарезом различались, причем различия достигали статистической значимости в отведении Р2 при воображении движений левой кисти $\left(F_{1,30}=5,10 ; p<0,05\right)$. Паттерн реактивности $\alpha$-ритма во время десятого сеанса отличался замещением реакций синхронизации в ряде отведений на десинхронизацию, что свидетельствует об увеличении активации неокортекса. Наиболее выраженными были изменения ЭЭГ у детей с левосторонним гемипарезом $\left(F_{20,300}=1,84 ; p<0,05\right)$. По завершении курса степень различия показателей ЭЭГ у пациентов с лево- и правосторонним гемипарезом уменьшилась. Выявленные перестройки паттерна ЭЭГ в частотной полосе а-ритма можно рассматривать как проявление процессов благоприятной реорганизации нейронных цепей, контролирующих планирование и выполнение сложных движений рук.

Ключевые слова: детский церебральный паралич, ЭЭГ, нейрореабилитация, интерфейс мозГ-компьютер, воображение движения

Финансирование: исследование выполнено в рамках темы: «Разработка комплекса экзоскелета кисти с внешним программным управлением и биологической обратной связью для процедуры реабилитации детей с синдромом ДЦП» при финансовой поддержке Министерства науки и высшего образования Российской Федерации (RFMEFI60519X0186).

Вклад авторов: Ларина Н. В., Корсунская Л. Л., Власенко С. В. - набор данных, написание статьи; Начарова М. А., Павленко В. Б. - обработка данных, написание статьи.

Соблюдение этических стандартов: исследование одобрено этическим комитетом КФУ им. В. И. Вернадского (протокол № 53 от 06 декабря 2018 г.). Все пациенты или их законные представители подписали добровольное информированное согласие.

$\triangle$ Для корреспонденции: Владимир Борисович Павленко

пр. Вернадского, 4, г. Симферополь, 295007; vpav55@gmail.com

Статья получена: 16.06.2020 Статья принята к печати: 02.07.2020 Опубликована онлайн: 16.07.2020

DOI: $10.24075 /$ vrgmu.2020.043

In most economically developed countries, cerebral palsy $(\mathrm{CP})$ is the leading cause of motor disability in children. CP affects 1 in 500 newborns; globally, there are 17 million people living with $\mathrm{CP}[1]$. CP is an umbrella term for the group of chronic nonprogressive motor impairments (spastic paresis, hyperkinetic disorder, cerebellar ataxia, pseudobulbar palsy) that stem from brain damage or developmental delay before, during or after birth. In patients with $\mathrm{CP}$, motor dysfunction 
usually co-exists with mental retardation, epilepsy, perceptual, learning or communication difficulties [2]. Because clinical manifestations of $\mathrm{CP}$ are very diverse, medications and physiotherapy may not always be effective. One of the most promising methods for managing motor dysfunction relies on the use of noninvasive brain-computer interfaces $(\mathrm{BCl})$ and robotic devices with biological feedback [3]. They are capable of recognizing a patient's motor intention from changes in his or her EEG during kinesthetic imagery followed by relevant activation of the robotic device. It is hypothesized [4] that robotic orthoses might significantly improve treatment outcomes: the patient receives feedback about how well the mental task is being performed whereas enhanced sensory input (tactile, proprioceptive or visual) stimulates brain structures that are fully or partially excluded from processing sensory information because to brain damage. This technology has been proved effective for post-stroke patients [5, 6].

Although it is reported that $\mathrm{BCl}$ might be a potent rehabilitation tool for children with $\mathrm{CP}[7,8]$, few studies have addressed this possibility so far. It was reported that individuals with $\mathrm{CP}$ could benefit from $\mathrm{BCl}$ that rely on the analysis of the sensorimotor EEG rhythm [9]. Kinesthetic imagery affected the power of the $\mu$ and $\beta$ EEG rhythms analyzed by a classifier. In another study, a BCl was used to, firstly, explore how the power ratio of the $\beta$ - to $\theta$-rhythms changed in patients who were mentally rehearsing a wrist extension movement and, secondly, trigger electrical stimulation of wrist extensors [10]. After a series of such $\mathrm{BCl}$-based session, children with $\mathrm{CP}$ demonstrated improvement in their hand movement parameters.

In another study, a BCl-controlled robotic hand was tested in children with $\mathrm{CP}$ undergoing rehabilitation at a medical health resort [11]. By the end of the neurorehabilitation course, the majority of the participants had achieved a reduction in wrist muscle spasticity, improved muscle strength, expanded the range of wrist movements and the repertoire of daily routines they were able to perform. By contrast, the only positive trend observed in the patients undergoing conventional treatment without $\mathrm{BCl}$-based training consisted in performing more daily tasks, but those improvements were statistically insignificant. At that point, EEG records were not analyzed.

Reactivity of the $\alpha$ - and $\mu$-rhythms is an attractive field for research, especially in the context of analysis of CNS activity in patients with motor impairment undergoing neurorehabilitation. The amplitude of the $\alpha$ - and $\mu$-rhythms can be attenuated or enhanced by physical or mental activity. These phenomena are called event-related desynchronization and synchronization, respectively. A study demonstrated that in healthy volunteers, certain patterns of $\alpha$-rhythm reactivity indicate involvement of various neocortical regions in processing sensory input from different modalities [12], whereas patterns of $\mu$-rhythm reactivity are indicative of activation in the somatosensory and motor cortex during motor execution and imagery $[13,14]$. The $\mu$-rhythm occurs in the alpha frequency range, which has a contribution from the occipital $\alpha$-rhythm during motor imagery; the occipital $\alpha$-rhythm is partially retained when the eyes are open and is characterized by high reactivity during cognitive activities [15]. So, the terms "the $\alpha$-rhythm" or "alpha rhythmic activity" used below will refer to the activity resulting from the $\alpha$ - and $\mu$-rhythms.

It was reported that these rhythms undergo synchronization or desynchronization in poststroke patients during motor imagery [16]. There were changes in the patterns of amplitude attenuation and enhancement following the rehabilitation course with a $\mathrm{BCl}$-controlled robotic hand. The researchers proposed that such reactivity might be indicative of the reorganization of neural circuits during neurorehabilitation. Today, the patterns of $\alpha$ - and $\mu$ - rhythm reactivity in children with $\mathrm{CP}$ remain understudied.

The aim of this paper was to describe the reactivity patterns of the EEG $\alpha$-rhythm during a series of neurorehabilitation sessions with a non-invasive $\mathrm{BCl}$-controlled robotic hand allowing biological feedback in CP-stricken children with a paretic upper limb.

\section{METHODS}

\section{Demographics}

The study was conducted at the Psychiatry and Neurology Unit of E.P. Glinka Yevpatoria Clinical Sanatorium for Children. The study recruited patients aged 10 to 18 years undergoing neurorehabilitation with a noninvasive $\mathrm{BCl}$-controlled robotic hand (Exohand-2) developed by Android Technics in collaboration with Pirogov Russian National Research Medical University and Institute of Higher Nervous Activity and Neurophysiology (Russia). The following inclusion criteria were applied: CP (according to ICD-10), hemiparesis, GMFCS (Gross Motor Function Classification System for Cerebral Palsy) level III or below. Patients at GMFCS level > III, with plegic upper limbs, aphasia, pharmacologically refractory epilepsy, or visual impairments preventing them from reading instructions on the computer screen, and those with moderate, severe or profound mental retardation (F71-73 according to ICD-10) were excluded from the study.

We shortlisted 32 patients, who were then referred to the medical health resort for rehabilitation. The patients were stratified into 2 groups: those with left-side hemiparesis (16 patients, including 10 boys and 6 girls) and those with rightside hemiparesis (16 children, including 9 boys and 7 girls). Of them, 21 patients were at GMFCS level II and 11 at GMFCS level III. There were 11 children aged 10-12 years, 12 children aged $13-15$ years, and 9 patients aged $16-18$ years. The mean age was $13.6 \pm 2.5$ years. The groups did not differ significantly in terms of age.

\section{Rehabilitation, EEG recording and analysis}

The device relies on the analysis of EEG patterns during motor imagery by a Bayesian classifier that analyzes covariance matrices of EEG signals [17].

During the sessions, the patients remained seated in armchairs at a $1.5 \mathrm{~m}$ distance from the computer screen where visual instructions were displayed. Their hands were inside the "glove" of the robotic hand. A round white fixation mark was displayed in the center of the screen, with 3 arrows around it that changed their color to present a task. The tasks included resting (the top arrow was activated for $10 \mathrm{~s}$ ) and kinesthetic imagery of right- or left-hand finger extension (the right or left arrows were activated for $10 \mathrm{~s}$ ). If the task was performed successfully, the fixation mark went green and the robotic hand extended passively. Thus, the patient received both visual and kinesthetic feedback.

Each patient received 10 rehabilitation sessions on alternate days, consisting of 38 -minute long trials with at least 5-minute breaks. For each hand, the movement was mentally rehearsed 24 times during one session. Apart from $\mathrm{BCl}$ sessions, the 21-day-long rehabilitation course included conventional therapy [11], specifically physical exercise, massage of the paretic muscles, peloid therapy, kinesiotherapy in thermal water, electrical stimulation of the antagonists of the paretic muscles. 
EEG was recorded in a monopolar fashion using a Neurovisor BMM electroencephalograph (Medical Computer Systems; Russia). Electrodes were placed according to the international 10-10 system over the frontal (Fpz, Fp1, Fp2, Fz, F1, F2, F3, F4), central (Cz, C1, C2, C3, C4), parietal (Pz, P1, P2, P3, P4), and occipital (Oz, O1, O2) lobes. An ear electrode was used as a reference. The cutoff values for high and low frequencies were 5 and $30 \mathrm{~Hz}$, respectively; the sampling rate was $500 \mathrm{~Hz}$.

EEG fragments with an amplitude over $250 \mu \mathrm{V}$ or containing a lot of artifacts pertaining to the electrical activity of forehead muscles were excluded from the analysis. EEG fragments recorded during mental rehearsal of the right/left hand movement and the resting stage (eyes open; baseline) that were $10 \mathrm{~s}$ long and free of artifacts were selected for further analysis. There were 10 to 15 such fragments for each task per session. These EEG fragments were processed with Fast Fourier transform (epoch time $2.5 \mathrm{~s}$, epoch overlap 50\%). The data were tapered using the Blackman window. For each 10-s long EEG fragment, we calculated the mean alpha amplitude for the frequency band of 8 to $13 \mathrm{~Hz}$ and the reactivity indices (RI) using the formula: $R I=100 \% \times[(B-A) / A]$, where $B$ is the mean $\alpha$-rhythm amplitude during the 10-s long motor imagery task and $A$ is the mean $\alpha$-rhythm amplitude in the resting phase (baseline condition) preceding the motor imagery task. For the right and left hands, mean $\mathrm{RI}$ values were calculated separately.

Positive RI values indicated an increase in the $\alpha$-rhythm amplitude during motor imagery relative to its baseline value (synchronization), whereas negative $\mathrm{Rl}$ values meant a reduction in the $\alpha$-rhythm amplitude (desynchronization). RI values from the $1^{\text {st }}$ and $10^{\text {th }}$ sessions were averaged and used in the subsequent analysis.

\section{Statistical analysis}

Statistical analysis was carried out in STATISTICA 10.0 (StatSoft Inc.; USA). The Shapiro-Wilk test revealed that the distribution of alpha RI values for all EEG leads was normal. Therefore,

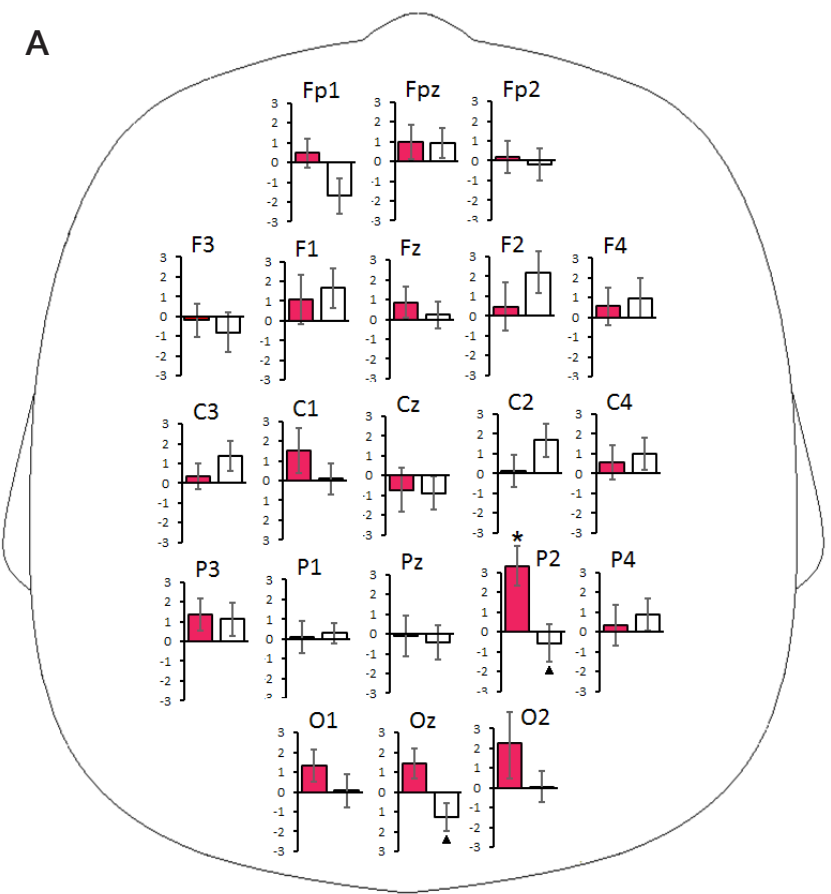

repeated measures ANOVA was applied to the obtained data. Using a $2 \times 2 \times 21$ design, we evaluated the effects of one intersubject factor GROUP (assignment to the group of subjects with right/left hemiparesis) and two intrasubject factors: HAND (mental rehearsal of the right/left hand movement) and LOCUS (position of one of 21 electrodes). Changes in $\alpha$-rhythm reactivity following rehabilitation were analyzed using ANOVA with 3 intrasubject factors: SESSION (1st and 10th), HAND and LOCUS. To assess Rl changes at each of electrode position, a priori contrasts were applied (the F-distribution test). Differences were considered significant at $p<0.05$, but due to the small sample size, we also kept track of trends $(p<0.10)$.

\section{RESULTS}

Previously, we demonstrated that rehabilitation with noninvasive $\mathrm{BCl}$-controlled robotic hand significantly improved motor function of the upper limbs in children with CP [11]. Patients who received only traditional rehabilitation therapy were unable to achieve statistically significant improvements. At that point, no analysis of EEG records was conducted.

\section{Alpha-rhythm reactivity at the beginning of the rehabilitation course}

Bidirectional modulations of the $\alpha$-rhythm amplitude were noted during motor imagery in the first session of $\mathrm{BCl}$-based therapy (Fig. 1, 2, red columns). Event-related synchronization was observed at most electrode sites in both hemispheres. Patterns of $\alpha$-rhythm modulations were different between children with right-side and left-side hemiparesis. The effect produced by the interaction of GROUP $\times$ HAND $\times$ LOCUS was close to statistically significant $\left(F_{20,600}=1.45 ; p=0.09\right)$. The a priori contrasts analysis revealed significant differences in $\alpha$-rhythm reactivity at $\mathrm{P} 2$ (the right parietal electrode; $F_{1,30}=5.10 ; p<0.05$ ) during mental practice of the left-hand movement (Fig.1) At P2, $\alpha$-rhythm synchronization was very pronounced in children with left-side hemiparesis (Fig. 1A), whereas children with right-side

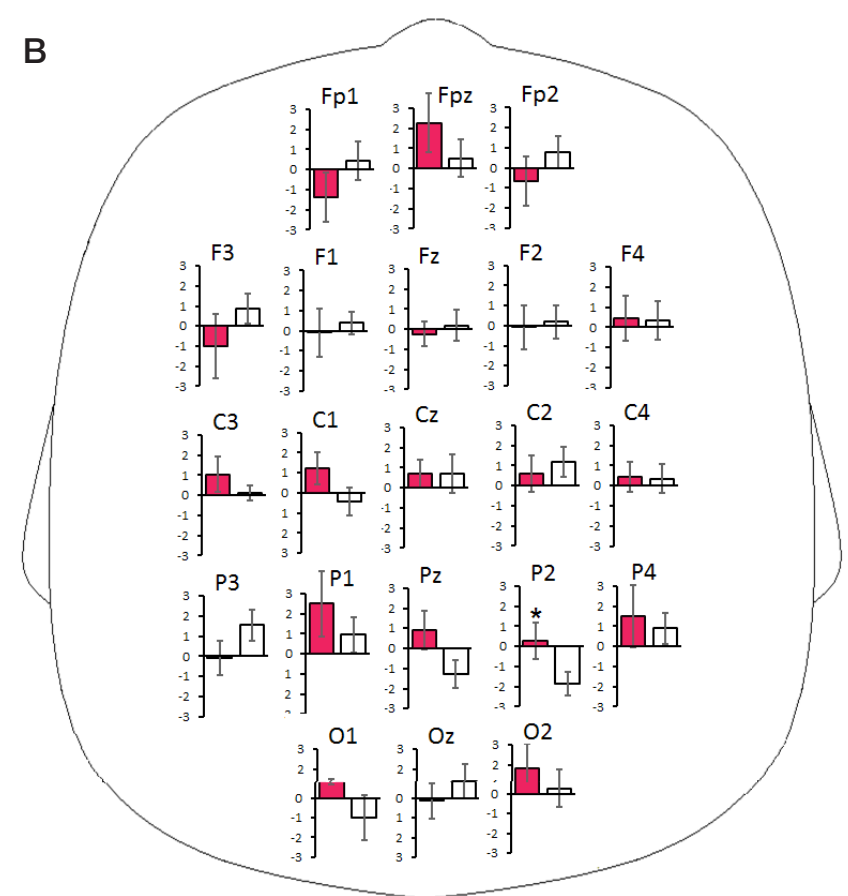

Fig. 1. Reactivity indices of the EEG $\alpha$-rhythm (\%) in children with left-side (A) and right-side (B) hemiparesis during mental rehearsal of the left-hand movement in the first session (red bars) and in the final session (white bars) of the $\mathrm{BCl}$-based rehabilitation course. The figure shows the mean values and standard errors. Differences in RI between the two groups are marked by * $(p<0.05)$ and between the sessions, by $\boldsymbol{\Delta}(p<0.05)$ 
hemiparesis demonstrated only a slight change in the $\alpha$-rhythm amplitude (Fig. 1B).

The a priori contrasts analysis uncovered a tendency to more pronounced $\alpha$-rhythm synchronization at $\mathrm{P} 2$ during righthand movement imagery in children with right-side hemiparesis $\left(F_{1,30}=2.81 ; p=0.10\right)$, as compared to those with left-side hemiparesis (Fig. 2A, B).

\section{Alpha-rhythm reactivity at the end of the rehabilitation course}

The pattern of $\alpha$-rhythm reactivity observed in our patients during the final session differed from that observed at the beginning of the rehabilitation course.

The impact of the SESSION $\times$ HAND $\times$ LOCUS combination $\left(F_{20,300}=1.84 ; p<0.05\right)$ on $\alpha$-rhythm reactivity was significant in children with left-side hemiparesis. Synchronization of the $\alpha$-rhythm during left-hand movement imagery observed at Fp1, Fp2, P2, and Oz at the beginning of the rehabilitation course now gave way to desynchronization (Fig. 1A). Differences in $\mathrm{Rl}$ values between the $1^{\text {st }}$ and $10^{\text {th }}$ sessions were statistically significant at P2 $\left(F_{1,15}=10.02\right.$; $p<0.01)$ and $\mathrm{Oz}\left(\mathrm{F}_{1,15}=7.68 ; p<0.05\right)$ and close to statistically significant at Fp1 ( $\left.{ }_{F 1,15}=3.96 ; p=0.07\right)$. Significant differences in $\alpha$-rhythm reactivity were detected at $\mathrm{C} 1$ $\left(F_{1,15}=6.57 ; p<0.05\right)$ in children with left-side hemiparesis during mental rehearsal of the right-hand movement. By the end of the rehabilitation course, synchronization had taken over desynchronization (Fig. 2A).

$\mathrm{Rl}$ values did not differ significantly between the $1^{\text {st }}$ and 10th sessions in children with right-side hemiparesis imagining right- and left-hand movements (Fig. 1B, 2B). The impact of the SESSION $\times$ HAND $\times$ LOCUS combination on $\alpha$-rhythm reactivity was insignificant $\left(F_{20,300}=0.86 ; p=0.64\right)$.

After the rehabilitation course was over, the differences in $\alpha$-rhythm reactivity between children with right- and left-side hemiparesis observed during motor imagery became much less pronounced: the impact of the GROUP $\times$ HAND $\times$ LOCUS

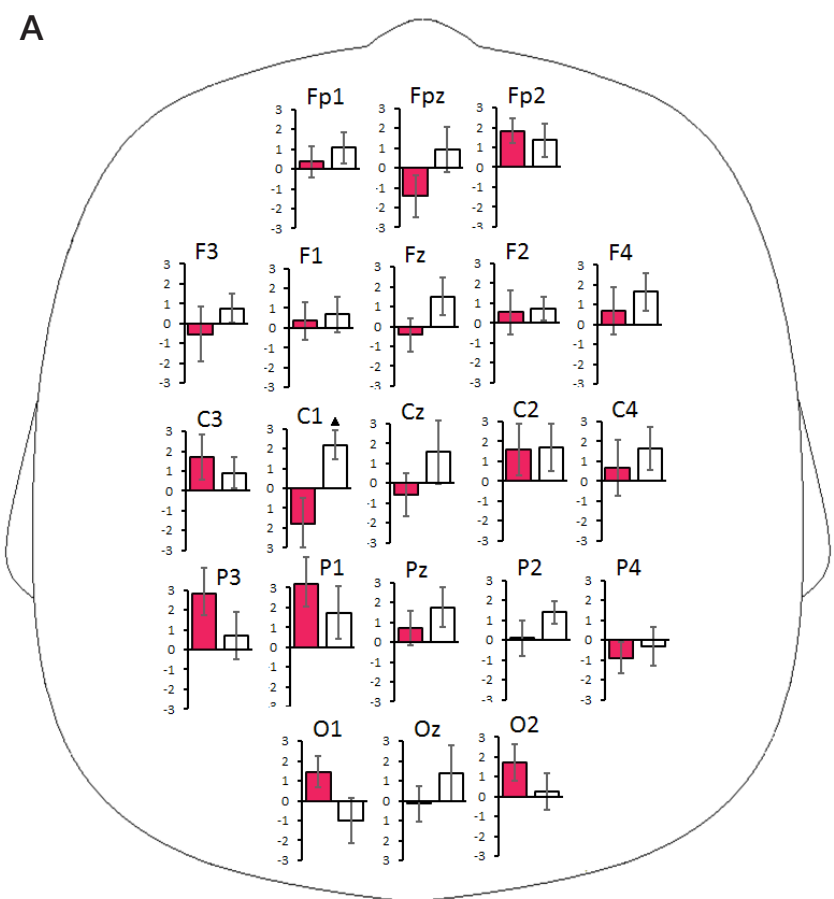

combination was now statistically insignificant $\left(F_{20,600}=0.88\right.$; $p=0.61)$.

\section{DISCUSSION}

This study analyzes changes in EEG signals during BCl-based neurorehabilitation of patients with CP. The EEG amplitude modulations in the alpha frequency band measured in children with CP during motor imagery was surprisingly low. At most electrode sites, RI values did not exceed $3 \%$. To some extent, this can be explained by the atypical modulation of EEG rhythms observed in patients with CP. Event-related $\mu$-rhythm synchronization and desynchronization responses during motor activity were weak in patients with $\mathrm{CP}$, as compared to healthy individuals. Those responses did not have distinct localization in patients with CP: EEG signal changes were observed in different neocortical regions, including the parietal and occipital lobes [18-20]. Besides, although our patients were asked to imagine movements continuously for 10 seconds, changes in $\alpha$-rhythm amplitude were not always solid. In healthy adults performing motor imagery tasks $\mu$-rhythm changes follow a multiphase pattern characterized by alternating synchronization and desynchronization [14]. The same alternating pattern of the $\mu$ - and $\alpha$-rhythms was observed during motor imagery in adult poststroke patients undergoing rehabilitation with robotic devices [16]. It is possible that in our study event-related synchronization and desynchronization responses appeared smoothed out because we analyzed the EEG amplitude for the entire period of motor imagery.

The pattern of $\alpha$-rhythm reactivity during motor imagery was bilateral. We saw the amplitude grow and decline not only in the contralateral but also in the ipsilateral hemisphere (relative to the hand the subject was focused on). Such atypical bilateral patterns of motor activity in children with CP were previously reported by other authors [21]. Using functional MRI, the researchers studied activation of CNS structures during motor imagery (grasping a ball) and recorded hand muscle responses to transcranial magnetic stimulation. The authors concluded

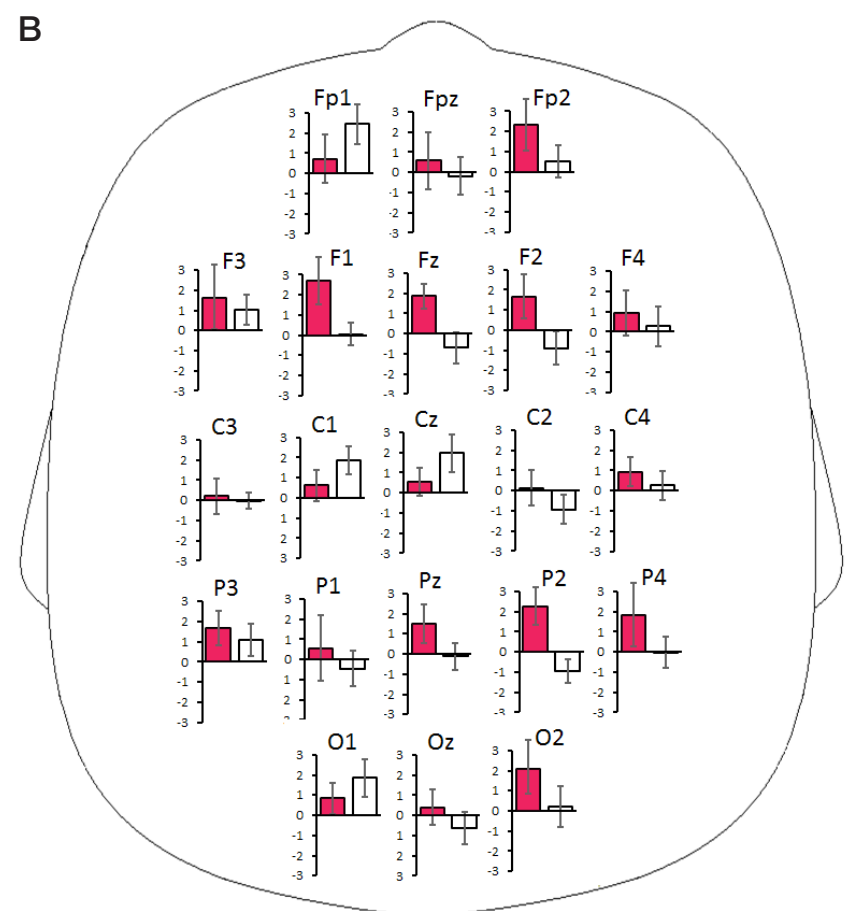

Fig. 2. Reactivity indices of the EEG $\alpha$-rhythm in children with left-side (A) and right-side $(\mathbf{B})$ hemiparesis during mental rehearsal of the right-hand movement in the first session and in the final session of the $\mathrm{BCl}$-based rehabilitation course. For legend see Fig. 1. 
that more than half of children with CP control the paretic hand with either ipsilateral or both hemispheres. Such unusual brain organization is probably compensatory; it develops after brain damage at early age and relies on the plasticity of the nervous system.

Our study was carried out in two groups of patients: with right- and left-side hemiparesis. This allowed us to compare EEG responses to motor imagery in the relatively intact and profoundly damaged hemispheres. At the beginning of the neurorehabilitation course, the patterns of $\alpha$-rhythm attenuation or enhancement during motor imagery differed between the groups. $\mathrm{RI}$ values were significantly different in the parietal lobe of the right hemisphere (P2). After the sessions, differences in the degree of $\alpha$-rhythm reactivity during motor imagery between children with left- and right-side hemiparesis became much less pronounced, probably indicating positive changes in CNS activity.

These changes are primarily associated with significant EEG reactivity in the alpha frequency band observed in patients with left-side hemiparesis at the end of the rehabilitation course. During the first $\mathrm{BCl}$ session, pronounced desynchronization ( $\mathrm{RI}>0.25 \%$ ) was observed only at one electrode site $(\mathrm{Cz})$ in this group of children, but during the final session, desynchronization was present in 6 regions of both hemispheres (Fig. 1A). Although changes in EEG reactivity patterns observed at the end of the course in children with right-side hemiparesis were not statistically significant, there still was an increase in $\alpha$-rhythm attenuation. During the first session, there were no signs of desynchronization at any of the electrode sites when the children were mentally rehearsing the movement of the paretic hand. However, in the final session, desynchronization was recorded at 6 electrode locations, mostly in the ipsilateral hemisphere (Fig. 2B). An increase in event-related $\alpha$-rhythm desynchronization suggestsincreased neocortical activation induced by neurorehabilitation [12-14]. An increase in desynchronization at P2 (Fig. 1A, B) is most noteworthy. The EEG signal at this location reflects the activity of the precuneal neural circuits [22]. The precuneus is profoundly involved in performing the broad spectrum of highly integrated tasks, including visuospatial motor imagery and first person perspective taking [23]. Increased activity of this brain region following neurorehabilitation may play a key role in the optimization of planning or executing complex hand movements and improved performance of daily activities.

Increased desynchronization in some neocortical regions was accompanied by event-related $\alpha$-rhythm enhancement in other cortical areas. Thus, there was a significant increase in the $\alpha$-rhythm amplitude in the primary motor $(\mathrm{C} 2, \mathrm{C} 4)$ and premotor (F2, F4) cortices in children with left-side hemiparesis as they were imagining the movement of the paretic hand. These changes occurring in the alpha frequency band are evident of active inhibition aimed at preventing the overinvolvement of the damaged contralateral hemisphere in motor activity control.

Because children with CP had significantly improved their motor function by the end of the rehabilitation course [11], the observed changes in EEG patterns in the alpha frequency band can be regarded as mirroring positive reorganization of neural circuits. This study is preliminary in nature. We cannot rule out the impact of factors associated with traditional rehabilitation modalities on the pattern of EEG reactivity. We are planning to conduct a randomized cross-sectional study to evaluate the impact of those factors and to analyze the link between EEG changes and motor improvements in children with CP. We think that this and future studies will help to elaborate new approaches to improving the efficacy of neurorehabilitation.

\section{CONCLUSIONS}

Neurorehabilitation of children with CP involving the use of noninvasive $\mathrm{BCl}$-controlled robotic hand significantly improves motor function of the upper limbs and changes the pattern of $\alpha$-rhythm reactivity during motor imagery. At the beginning of the rehabilitation course, the patterns of $\alpha$-rhythm reactivity differed significantly between children with left- and rightside hemiparesis. By the end of the course, the differences became much less pronounced, suggesting positive changes in CNS activity. These improvements result from a statistically significant change in EEG reactivity patterns in patients with left-side hemiparesis. On the whole, children with left- and rightside hemiparesis demonstrated an increase in the proportion of $\alpha$-rhythm desynchronization responses, indicating increased neocortical activity following neurorehabilitation. The observed changes in the EEG patterns in the alpha frequency band reflect increased plasticity of the neural circuits responsible for planning and executing complex hand movements.

\section{References}

1. Graham HK, Rosenbaum P, Paneth N, Dan B, Lin JP, Damiano DL, et al. Cerebral palsy. Nat Rev Dis Primers. 2016; 2: 15082. DOl: 10.1038/nrdp.2015.82.

2. Patel DR, Neelakantan M, Pandher K, Merrick J. Cerebral palsy in children: a clinical overview. Transl Pediatr. 2020; 9 (Suppl 1): 125-35.

3. Frolov AA, Bobrov PD. Interfejs mozg-komp'juter: nejrofiziologicheskie predposylki i klinicheskoe primenenie. Zhurnal vysshej nervnoj dejatel'nosti im. I. P. Pavlova. 2017; 67 (4): 365-76. Russian.

4. Chiew M, LaConte S, Graham S. Investigation of fMRI neurofeedback of differential primary motor cortex activity using kinesthetic motor imagery. Neurolmage. 2012; 61 (1): 21-31.

5. Kotov SV, Turbina LG, Bobrov PD, Frolov AA, Pavlova OG Kurganskaja ME i dr. Reabilitacija bol'nyh, perenesshih insul't, s pomoshh'ju bioinzhenernogo kompleksa «interfejs mozgkomp'juter + jekzoskelet». Zhurnal nevrologii i psihiatrii im. C. C. Korsakova. 2014; 114 (12-2): 66-72. Russian.

6. Frolov AA, Mokienko OA, Lyukmanov RKh, Chernikova LA, Kotov SV, Turbina LG et al. Preliminary results of a controlled study of $\mathrm{BCl}$-exoskeleton technology efficacy in patients with poststroke arm paresis. Bulletin of RSMU. 2016; 2: 16-23.

7. Ponce P, Molina A, Balderas DC, Grammatikou D. Brain Computer Interfaces for Cerebral Palsy. In: E. Suraka, editor. Cerebral Palsy challenges for the future. London: IntechOpen, 2014; p. 245-72. DOI: $10.5772 / 57084$

8. Jochumsen M, Shafique M, Hassan A, Niazi IK. Movement intention detection in adolescents with cerebral palsy from singletrial EEG. J Neural Eng. 2018; 15 (6): 066030. DOI: 10.1088/17412552/aae4b8.

9. Daly I, Billinger M, Laparra-Hernández J, Aloise F, Lloria García M, Faller J, et al. On the control of brain-computer interfaces by users with cerebral palsy. Clin Neurophysiol. 2013; 124 (9): 1787-97.

10. Kim T-W, Lee B-H. Clinical usefulness of brain-computer interfacecontrolled functional electrical stimulation for improving brain activity in children with spastic cerebral palsy: a pilot randomized controlled trial. J Phys Ther Sci. 2016; 28 (9): 2491-4.

11. Larina NV, Korsunskaya LL, Vlasenko SV. The "Exo hand-2" complex in the rehabilitation of the upper limb in cerebral palsy using the non-invasive interface "brain-computer". Neuromuscular 
diseases. 2019; 11 (4): 12-20. Russian

12. Bazanova OM, Vernon D. Interpreting EEG alpha activity. Neurosci Biobehav Rev. 2014; 44: 94-110.

13. Pfurtscheller G, Brunner C, Schlögl A, Lopes da Silva FH. Mu rhythm (de)synchronization and EEG single-trial classification of different motor imagery tasks. Neurolmage. 2006; 31 (1): 153-9.

14. Llanos C, Rodriguez M, Rodriguez-Sabate C, Morales I, Sabate M. Mu-rhythm changes during the planning of motor and motor imagery actions. Neuropsychologia. 2013; 51 (6): 1019-26.

15. Klimesch W. Alpha-band oscillations, attention, and controlled access to stored information. Trends Cogn Sci. 2012; 16 (12) 606-17.

16. Kotov SV, Romanova MV, Kondur AA, Biryukova EV, Frolov AA, Turbina LG i dr. Reorganizacija biojelektricheskoj aktivnosti neokorteksa posle insul'ta v rezul'tate reabilitacii s ispol'zovaniem interfejsa «mozg-komp'juter», upravljajushhego jekzoskeletom kisti. Zhurnal vysshej nervnoj dejatel'nosti im. I. P. Pavlova. 2020 70 (2): 217-30. Russian.

17. Bobrov PD, Korshakov AV, Roshhin VYu, Frolov AA. Bajesovski podhod $k$ realizacii interfejsa mozg-komp'juter, osnovannogo na predstavlenii dvizhenij. Zhurnal vysshej nervnoj dejatel'nosti im. I. P. Pavlova. 2012; 62 (1): 89-99. Russian.

18. Shin YK, Lee DR, Hwang HJ, You SJ, Im CH. A novel EEG-based

\section{Литература}

1. Graham HK, Rosenbaum P, Paneth N, Dan B, Lin JP, Damiano DL, et al. Cerebral palsy. Nat Rev Dis Primers. 2016; 2: 15082. DOl: 10.1038/nrdp.2015.82.

2. Patel DR, Neelakantan M, Pandher K, Merrick J. Cerebral palsy in children: a clinical overview. Transl Pediatr. 2020; 9 (Suppl 1): 125-35.

3. Фролов А. А., Бобров П. Д. Интерфейс мозг-компьютер: нейросизиологические предпосылки и клиническое применение. Журнал высшей нервной деятельности им. И.П. Павлова. 2017; 67 (4): 365-76.

4. Chiew M, LaConte S, Graham S. Investigation of fMR neurofeedback of differential primary motor cortex activity using kinesthetic motor imagery. Neurolmage. 2012; 61 (1): 21-31.

5. Котов С. В., Турбина Л. Г., Бобров П. Д., Фролов А. А. Павлова О. Г., Курганская М. Е. и др. Реабилитация больных, перенесших инсульт, с помощью биоинженерного комплекса «интерфейс мозг-компьютер + экзоскелет». Журнал неврологии и психиатрии им. С. С. Корсакова. 2014; 114 (12-2): 66-72.

6. Фролов А. А., Мокиенко О. А., Люкманов Р. Х., Черникова Л. А., Котов С. В., Турбина Л. Г. и др. Предварительные результаты контролируемого исследования эффективности технологии ИМК-экзоскелет при постинсультном парезе руки. Вестник РГМУ. 2016; 2: 17-25.

7. Ponce P, Molina A, Balderas DC, Grammatikou D. Brain Computer Interfaces for Cerebral Palsy. In: E. Suraka, editor. Cerebral Palsy challenges for the future. London: IntechOpen, 2014; p. 245-72. DOI: $10.5772 / 57084$.

8. Jochumsen M, Shafique M, Hassan A, Niazi IK. Movement intention detection in adolescents with cerebral palsy from singletrial EEG. J Neural Eng. 2018; 15 (6): 066030. DOI: 10.1088/17412552/aae4b8.

9. Daly I, Billinger M, Laparra-Hernández J, Aloise F, Lloria García M, Faller J, et al. On the control of brain-computer interfaces by users with cerebral palsy. Clin Neurophysiol. 2013; 124 (9): 1787-97.

10. Kim T-W, Lee B-H. Clinical usefulness of brain-computer interfacecontrolled functional electrical stimulation for improving brain activity in children with spastic cerebral palsy: a pilot randomized controlled trial. J Phys Ther Sci. 2016; 28 (9): 2491-4.

11. Ларина Н. В., Корсунская Л. Л., Власенко С. В. Комплекс «Экзокисть-2» в реабилитации верхней конечности при детском церебральном параличе с использованием неинвазивного интерфейса «мозг-компьютер». Нервномышечные болезни. 2019; 11 (4): 12-20.

12. Bazanova OM, Vernon D. Interpreting EEG alpha activity. Neurosci brain mapping to determine cortical activation patterns in normal children and children with cerebral palsy during motor imagery tasks. Neurorehabilitation. 2012; 31 (4): 349-55.

19. Inuggi $A$, Bassolino $M$, Tacchino $C$, Pippo $V$, Bergamaschi $V$, Campus C, et al. Ipsilesional functional recruitment within lower mu band in children with unilateral cerebral palsy, an event-related desynchronization study. Exp Brain Res. 2018; 236 (2): 517-27.

20. Démas $J$, Bourguignon $M$, Périvier $M$, De Tiège $X$, Dinomais $M$, Van Bogaert P. Mu rhythm: State of the art with special focus on cerebral palsy. Annals of Physical and Rehabilitation Medicine [Internet]. 2019 June [cited 2019 July 9]. Available from: https:// doi.org/10.1016/. rehab.2019.06.007.

21. Weinstein M, Green D, Rudisch J, Benthem M, Zielinski IM, Jongsma MLA, et al. Understanding the relationship between brain and upper limb function in children with unilateral motor impairments: A multimodal approach. Eur J Paediatr Neurol. 2018; 22 (1): 143-54.

22. Koessler L, Maillard L, Benhadid A, Vignal JP, Felblinger J, Vespignani $\mathrm{H}$, et al. Automated cortical projection of $\mathrm{EEG}$ sensors: Anatomical correlation via the international 10-10 system. Neurolmage. 2009; 46 (1): 64-72.

23. Cavanna AE, Trimble MR. The precuneus: a review of its functional anatomy and behavioural correlates. Brain. 2006; 12 (30): 564-83.

Biobehav Rev. 2014; 44: 94-110.

13. Pfurtscheller G, Brunner C, Schlögl A, Lopes da Silva FH. Mu rhythm (de)synchronization and EEG single-trial classification of different motor imagery tasks. Neurolmage. 2006; 31 (1): 153-9.

14. Llanos C, Rodriguez M, Rodriguez-Sabate C, Morales I, Sabate M. Mu-rhythm changes during the planning of motor and motor imagery actions. Neuropsychologia. 2013; 51 (6): 1019-26.

15. Klimesch W. Alpha-band oscillations, attention, and controlled access to stored information. Trends Cogn Sci. 2012; 16 (12): 606-17.

16. Котов С. В., Романова М. В., Кондур А. А., Бирюкова Е. В., Фролов А. А., Турбина Л. Г. и др. Реорганизация биоэлектрической активности неокортекса после инсульта в результате реабилитации с использованием интерфейса «мозг-компьютер», управляющего экзоскелетом кисти. Журнал высшей нервной деятельности им. И. П. Павлова. 2020; 70 (2): 217-30.

17. Бобров П. Д., Коршаков А. В., Рощин В. Ю., Фролов А. А Байесовский подход к реализации интерфейса мозгкомпьютер, основанного на представлении движений. Журнал высшей нервной деятельности им. И. П. Павлова. 2012; 62 (1): 89-99.

18. Shin YK, Lee DR, Hwang HJ, You SJ, Im CH. A novel EEG-based brain mapping to determine cortical activation patterns in normal children and children with cerebral palsy during motor imagery tasks. Neurorehabilitation. 2012; 31 (4): 349-55.

19. Inuggi A, Bassolino M, Tacchino C, Pippo V, Bergamaschi V, Campus C, et al. Ipsilesional functional recruitment within lower mu band in children with unilateral cerebral palsy, an event-related desynchronization study. Exp Brain Res. 2018; 236 (2): 517-27.

20. Démas J, Bourguignon $M$, Périvier $M$, De Tiège $X$, Dinomais $M$, Van Bogaert P. Mu rhythm: State of the art with special focus on cerebral palsy. Annals of Physical and Rehabilitation Medicine [Internet]. 2019 June [cited 2019 July 9]. Available from: https:// doi.org/10.1016/. .rehab.2019.06.007.

21. Weinstein M, Green D, Rudisch J, Benthem M, Zielinski IM, Jongsma MLA, et al. Understanding the relationship between brain and upper limb function in children with unilateral motor impairments: A multimodal approach. Eur J Paediatr Neurol. 2018; 22 (1): 143-54.

22. Koessler L, Maillard L, Benhadid A, Vignal JP, Felblinger J, Vespignani $\mathrm{H}$, et al. Automated cortical projection of $\mathrm{EEG}$ sensors: Anatomical correlation via the international 10-10 system. Neurolmage. 2009; 46 (1): 64-72.

23. Cavanna AE, Trimble MR. The precuneus: a review of its functional anatomy and behavioural correlates. Brain. 2006; 12 (30): 564-83. 


\title{
THROMBOGENICITY IN PATIENTS WITH ISCHEMIC STROKE AND PRE-EXISTING POLYCYTHEMIA VERA
}

Tanashyan $\mathrm{MM}^{1}$, Shabalina $\mathrm{AA}^{1} \otimes$, Roitman $\mathrm{EV}^{1}$, Vavilova $\mathrm{TV}^{2}$, Kuznetsova $\mathrm{PI}^{1}$

${ }^{1}$ Research Center of Neurology, Moscow, Russia

${ }^{2}$ Almazov National Medical Research Centre, Saint Petersburg, Russia

\begin{abstract}
Thrombogenicity and its causes in patients with ischemic stroke (IS) and pre-existing polycythemia vera (PV) is a significant clinical concern. The aim of this study was to identify the range of factors associated with increased thrombogenicity in patients with IS and pre-existing PV. We performed a physical examination and laboratory tests on 127 patients in the hyperacute stroke stage and 16-18 months after. Of them, 68 patients had PV (the main group) and 59 did not have this condition (the comparison group). Laboratory tests were conducted to evaluate blood rheology, hemostasis, endothelial function, angiogenesis, proinflammatory cytokine levels; we also tested patients for the presence of the V617F mutation in the JAK2 gene and analyzed the contribution of all studied parameters to the development of thrombotic and hemorrhagic complications. We found that the neurological picture did not differ between the groups: mean NIHSS scores were 12 and 13 points, respectively. Morphological and functional characteristics of red blood cells and platelets, hemostasis and cytokine profiles were compared between patients with IS and pre-existing PV and the comparison group. One of the key elements in potentiating thrombotic complications in patients with IS and PV was JAK2 V617F allele burden. The obtained data suggest the cumulative effect of the identified factors promoting thrombus formation in post-stroke patients with PV and overpowering the effect of antiplatelet therapy.
\end{abstract}

Keywords: ischemic stroke, polycythemia vera, thrombosis, blood rheology, hemostasis, angiogenesis

Author contribution: Tanashyan MM — study concept and design; discussion and manuscript preparation; Shablina AA — literature analysis; data acquisition and statistical analysis; results discussion; Roitman EV, Vavilova TV — literature analysis; results discussion; Kuznetsova PI — patient histories; results discussion.

Compliance with ethical standards: the study was approved by the local Ethics Committee (Protocol № 1-4/18 dated February 7, 2018). Informed consent was obtained from all study participants.

$\triangle$ Correspondence should be addressed: Alla A. Shabalina

Volokolamskoe shosse, 80/1, Moscow, 125367; shabalina@neurology.ru

Received: 11.08.2020 Accepted: 25.08.2020 Published online: 31.08.2020

DOI: $10.24075 /$ brsmu.2020.052

\section{ТРОМБОГЕННОСТЬ У БОЛЬНЫХ ИШЕМИЧЕСКИМ ИНСУЛЬТОМ НА ФОНЕ ИСТИННОЙ ПОЛИЦИТЕМИИ}

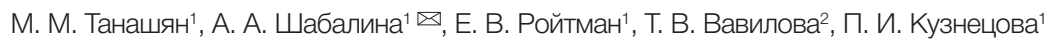

${ }^{1}$ Научный центр неврологии, Москва, Россия

${ }^{2}$ Национальный медицинский исследовательский центр имени В. А. Алмазова, Санкт-Петербург, Россия

Проблема возникновения и возможные причины тромбогенности у пациентов с ишемическим инсультом (ИИ) на фоне истинной полицитемии (ИП) остается актуальной. Целью исследования было определить комплекс факторов, ассоциированных с формированием высокой тромбогенности у пациентов с ИИ на фоне ИП. Проведено комплексное клинико-лабораторное обследование 127 пациентов в острейшем периоде ИИ и спустя 16-18 месяцев: 68 пациентов с ИИ на фоне истинной полицитемии ИП (основная группа) и 59 пациентов с ИИ без ИП (группа сравнения). Лабораторное обследование включало определение гемореологических параметров, показателей системы гемостаза, функции эндотелия, активности ангиогенеза, цитокинового и воспалительного ряда, молекулярно-генетическое исследование мутации V617F в гене JAK2 и анализ вклада их изменений в развитие тромбогеморрагических осложнений. Обнаружено, что неврологическая картина в обеих группах была без значимых различий со средней оценкой по шкале NIHSS 12 и 13 баллов соответственно. Отмечены особенности морфофункциональных характеристик эритроцитов и тромбоцитов, а также гемостазиологического и цитокинового профиля у пациентов с ИИ на фоне ИП по сравнению с группой сравнения. Одним из ключевых элементов в потенциировании тромботических осложнений у пациентов с ИИ и ИП стала величина аллельной нагрузки мутации V617F в гене JAK2. Полученные данные свидетельствуют о совокупном действии комплекса факторов, формирующих высокую тромбогенность у перенесших ИИ пациентов с ИП и преодолевающих суммарный эффект антитромботической терапии.

Ключевые слова: ишемический инсульт, истинная полицитемия, тромбоз, гемореология, гемостаз, ангиогенез

Вклад авторов: М. М.Танашян — идеология и дизайн исследования, обсуждение результатов и редактирование рукописи; А. А. Шабалина — литературный обзор, сбор и анализ материала, статистическая обработка данных, обсуждение результатов; Е. В. Ройтман, Т. В. Вавилова - литературный обзор, обсуждение результатов; П. И. Кузнецова - описание клинического материала, обсуждение результатов.

Соблюдение этических стандартов: исследование одобрено локальным этическим комитетом (протокол № 1-4/18 от 07 февраля 2018 г.). Все пациенть подписали информированное согласие на проведение обследований.

$\bowtie$ Для корреспонденции: Алла Анатольевна Шабалина

Волоколамское шоссе, д. 80/1, г. Москва, 125367; shabalina@neurology.ru

Статья получена: 11.08.2020 Статья принята к печати: 25.08.2020 Опубликована онлайн: 31.08.2020

DOI: $10.24075 /$ vrgmu.2020.052

Despite phenotypic heterogeneity, all subtypes of ischemic stroke (IS) share a common underlying mechanism: interruption of micro-and macrovascular blood flow in brainsupplying vessels.. Thrombosis develops as a complex multifactorial process involving changes in blood rheology, loss of antithrombotic properties by the endothelium, initiation of systemic inflammatory response, and homeostatic imbalance $[1,2]$. Cerebrovascular disorders (CVD) often strike in the setting of Ph-negative myeloproliferative neoplasms (MPN) $[3,4]$. Polycythemia vera (PV) is a Ph-negative MPN that causes severe, frequent thrombohemorrhagic complications, including CVD. PV arises from myeloproliferation of hematopoietic stem cells in the bone marrow followed by successful terminal differentiation of hematopoietic progenitors into mature cells. This results in the sustained elevation of hemoglobin and erythrocyte count in the peripheral blood $[5,6]$. 